Social impact scaling strategies in social enterprises: A systematic review and research agenda

\author{
Syrus M. Islam \\ Auckland University of Technology \\ Auckland, New Zealand \\ Email: syrus.islam@aut.ac.nz
}

Suggested citation:

Islam, S. M. (2021). "Social impact scaling strategies in social enterprises: A systematic review and research agenda", Australian Journal of Management (forthcoming). https://doi.org/10.1177/03128962211014931 


\title{
Social impact scaling strategies in social enterprises: A systematic review and research agenda
}

\begin{abstract}
Social enterprises have attracted increased attention from both researchers and practitioners around the world. In the social enterprise context, scaling social impact is considered the main currency or key performance metric. Two overarching social impact scaling strategies are organizational growth strategy and ecosystem growth strategy. However, to date, little cumulative knowledge exists on these two social impact scaling strategies. To address this issue, this paper conducts a systematic review of 111 peer-reviewed articles. It identifies and discusses key insights into organizational growth strategy and ecosystem growth strategy as a means to scale social impact in social enterprises. Based on these findings, the current paper also develops a framework to facilitate a comprehensive understanding of social impact scaling strategies in social enterprises. Finally, the review identifies gaps in the existing literature and discusses a comprehensive agenda for future research.
\end{abstract}

Keywords: Social impact; Scaling strategy; Organizational growth; Ecosystem growth; Social enterprise; Social entrepreneurship 


\section{Introduction}

Over the past two decades, the phenomenon of social enterprises (SEs) has attracted increased scholarly attention (Dacin et al., 2011; Saebi et al., 2019). Broadly, SEs are organizations that primarily aim to solve pressing social/environmental problems (e.g., homelessness, youth unemployment, and carbon emissions) whilst engaging in commercial activities (either partially or fully) to support their operations (Doherty et al., 2014). They can take several forms such as cooperatives, development trusts, trading arms of charities, credit unions, and community enterprises (Vickers and Lyon, 2014; Powell et al., 2019). In the SE context, scaling social impact is considered the main currency (e.g., Bacq and Eddleston, 2018; Molecke and Pinkse, 2017). Scaling social impact refers to "an ongoing process of increasing the magnitude of both quantitative and qualitative positive changes in society by addressing pressing social problems at individual and/or systemic levels through one or more scaling paths" (Islam, 2020a: 1).

To scale their social impact, SEs use several strategies that are usually grouped under two overarching strategies. The first one is organizational growth strategy that refers to directly addressing a certain social problem on a large scale by growing organizational size (e.g., Vickers and Lyon, 2014; Vickers et al., 2017; Dees et al., 2004; Lyon and Fernandez, 2012). As an overarching strategy, organizational growth strategy encompasses several more specific strategies that aim to improve beneficiary wellbeing by developing new products, services, activities, and programs, as well as expanding geographic coverage to reach larger numbers of beneficiaries (e.g., Bacq and Eddleston, 2018; Desa and Koch, 2014; Bhatt et al., 2016; Dobson et al., 2018; Alshawaaf and Lee, 2020). The second overarching strategy is ecosystem growth strategy that refers to indirectly addressing targeted social problems on a large scale by growing and/or sustaining a supportive SE ecosystem (e.g., Thompson et al., 2018; Bloom and Dees, 2008; Montgomery et al., 2012; VanSandt et al., 2009). As an overarching strategy, ecosystem 
growth strategy includes several more specific strategies that focus on growing or sustaining a supportive SE ecosystem as a means to make positive changes in society through activities such as organizing advocacy campaigns, developing and disseminating valuable knowledge and research, providing training and advisory services to other SEs, helping young and lessreputed SEs to gain and maintain legitimacy, etc. (e.g., Islam, 2020b; Bauwens et al., 2020; Bloom and Chatterji, 2009; Granados and Rosli, 2020; Maseno and Wanyoike, 2020; Westley et al., 2014).

As organizational growth strategy and ecosystem growth strategy are generally considered two overarching social impact scaling strategies in SEs, the current review centers on these two strategies. This paper fills an important gap in the SE literature in that although research in the SE field is rapidly growing (Saebi et al., 2019), little cumulative knowledge exists on organizational growth strategy and ecosystem growth strategy as a means to scale social impact in SEs. To address this issue, thereby helping the advancement of SE research in a less fragmented way, the current paper conducts a systematic review of 111 peer-reviewed articles drawn from a wide range of journals. The review shows that while scaling social impact, organizational growth strategy has remained a popular one, under which SEs pursue two major activities, as will be discussed later. In contrast, while scaling social impact through ecosystem growth strategy, SEs undertake eight major activities. Key insights into each of these major activities are identified and discussed. The review also shows that although ecosystem growth strategy can create greater social impact by addressing pressing social problems at a larger scale beyond the organizational boundary, relatively lower scholarly attention has been paid to it. In addition, this review has highlighted the limitations or potential unintended consequences of various social impact scaling strategies. Finally, the current paper proposes several promising future research avenues, thus providing clear directions to scholars interested in researching the phenomenon of scaling social impact in SEs. 


\section{Methods}

\subsection{Data collection and cleaning}

To identify relevant articles, three sets of keywords were developed following a systematic procedure. First, to gain an initial understanding of various terms that are used interchangeably with the term "social enterprise", we consulted a few prominent articles (both review and nonreview articles) on social enterprises and social entrepreneurship (e.g., Austin et al., 2006; André and Pache, 2016; Battilana et al., 2015; Tracey and Jarvis, 2007; Saebi et al., 2019; Doherty et al., 2014). Based on our reading of these articles, we drafted an initial list of more than 15 keywords. To assess the suitability of these keywords, we searched them in various combinations in the Scopus database. Gradually, it became clear that many of these keywords were not adding any extra value in terms of search results, rather causing unnecessary duplication of effort. Therefore, to ensure inclusivity and focus while minimizing the duplication of effort, the following keywords were finalized: "social enterprise", "social business", "social venture", "social entrepreneurship", "social sector", "third sector", "hybrid organization", and "hybrid organisation".

Second, the keywords for "social impact" were also selected following a systematic approach. Initially, we drafted more than 12 keywords after reviewing a number of prior articles (e.g., Ebrahim and Rangan, 2014; Di Domenico et al., 2010; Molecke and Pinkse, 2017; Bacq and Eddleston, 2018; Bloom and Chatterji, 2009; Desa and Koch, 2014). We searched them in several combinations in the Scopus database, but found that many were not adding any extra

\footnotetext{
${ }^{1}$ Following prior review articles on social enterprises and social entrepreneurship (see Doherty et al., 2014; HladyRispal and Servantie, 2018), the current review considers social enterprises as an overarching form of organizations that pursue social goals and adopt some type of commercial activity to generate revenue, regardless of their different forms. Distinguishing different forms of social enterprises is beyond the scope of the current review.
} 
value in the search results. Hence, we dropped them and finalized the following set of keywords: "social impact", "social value", "social performance", "social change", "environmental performance", and "environmental impact". Third, following the same systematic procedure as mentioned above, we finalized the following list of keywords to capture the theme of "scaling" after reviewing several prior articles (e.g., Islam, 2020a; Bloom and Chatterji, 2009; Easter and Conway Dato-On, 2015; Ormiston and Seymour, 2011; Perrini et al., 2010): "scal*", "increas*", and "creat*".2

Drawing on Saebi et al. (2019) and Shepherd et al. (2015), the above three sets of keywords were searched in the Scopus database (using its article title, abstract, or keywords feature) in the following fashion, without placing boundaries on the time period: any of the words from the first set of keywords AND any of words from the second set of keywords AND any of the words from the third set of keywords. This search generated a list of 622 articles. The same search was also carried out in the Web of Science database, which resulted in 406 articles.

Next, drawing on Doherty et al. (2014) and Saebi et al. (2019), to obtain a manageable and quality sample of articles, the search was limited to i) peer-reviewed articles (in English) and ii) journals rating from 2 to $4^{*}$ by the Chartered Association of Business Schools $(2018)^{3}$. This resulted in 170 articles in Scopus and 121 articles in Web of Science. Following Shepherd et al. (2015) and Saebi et al. (2019), data was manually cleaned by excluding i) duplicate articles between the two databases, ii) articles that were mainly summaries of articles published elsewhere, book reviews, teaching cases, a research methods article, and iii) articles that

\footnotetext{
${ }^{2}$ The Scopus and Web of Science databases employed in the current paper use lemmatization in the search, hence automatically retrieve both singular and plural forms of a keyword. For example, "social enterprise" finds both social enterprise and social enterprises. The wildcard (*) was mainly used to locate multiple variants of a keyword, going beyond singular and plural forms. For example, "scal*" finds scale, scaling, scalability, etc. Also, where applicable, both American and British English variants are included in the keywords (e.g., "hybrid organization" and "hybrid organisation").

${ }^{3}$ Journals rating from 2 to $4^{*}$ by the Chartered Association of Business Schools (2018) are roughly equivalent to journals rating from B to A* by the Australian Business Deans Council (2019).
} 
contained little or no discussion about organizational growth strategy or ecosystem growth strategy in the context of scaling social impact in SEs. This left a total of 80 articles.

Also, drawing on Doherty et al. (2014) and Linnenluecke et al. (2020), this paper employed a reverse search technique to source additional articles from the citations in these 80 articles. This generated a further 31 articles by following two main inclusion criteria: i) peer-reviewed articles (in English), and ii) articles must contain substantial discussion about scaling social impact through organizational growth strategy or ecosystem growth strategy in the SE context. These additional articles were not detected in the initial search because, for example, the publication titles (e.g., Stanford Social Innovation Review) were not included in the search databases and search terms were missing in the article title, abstract and keywords. Overall, the final list contains 111 articles (cut-off: 26 October 2020; see Appendix for a complete list).

\subsection{Data coding and analysis}

The articles in the final sample were coded and analyzed in several iterative stages. As noted above, organizational growth strategy and ecosystem growth strategy are generally considered two overarching social impact scaling strategies in SEs. Therefore, in the first stage, by thoroughly reviewing the contents of each article, articles were categorized into two broader groups: organizational growth strategy and ecosystem growth strategy. More specifically, articles, whose primary focus was addressing social problems on a large scale through activities related to the growth of organizational size, were grouped under organizational growth strategy (e.g., Lyon and Fernandez, 2012; Hlady-Rispal and Servantie, 2017; Huybrechts et al., 2017). On the other hand, articles, whose primary focus was addressing social problems on a large scale through activities related to the growth and/or sustainment of a supportive SE ecosystem, were grouped under ecosystem growth strategy (e.g., Thompson et al., 2018; Montgomery et al., 2012; VanSandt et al., 2009). 
In the second stage, articles under organizational growth strategy were analyzed to identify key insights into this overarching social impact scaling strategy. These insights are discussed around the following major themes that emerged from the analysis: product/service expansion and geographic expansion (see Figure 1 for a summary of key insights generated in this regard). In the third stage, articles under ecosystem growth strategy were analyzed to identify key insights into this overarching strategy. These insights are presented around the following major themes that emerged from our analysis: advocacy work, coalition work, industry work, training and advisory work, infrastructure work, legitimacy work, research and publication work, and financing work (see Figure 1 for a summary of key insights developed in this regard).

--- Insert Figure 1 here --- 


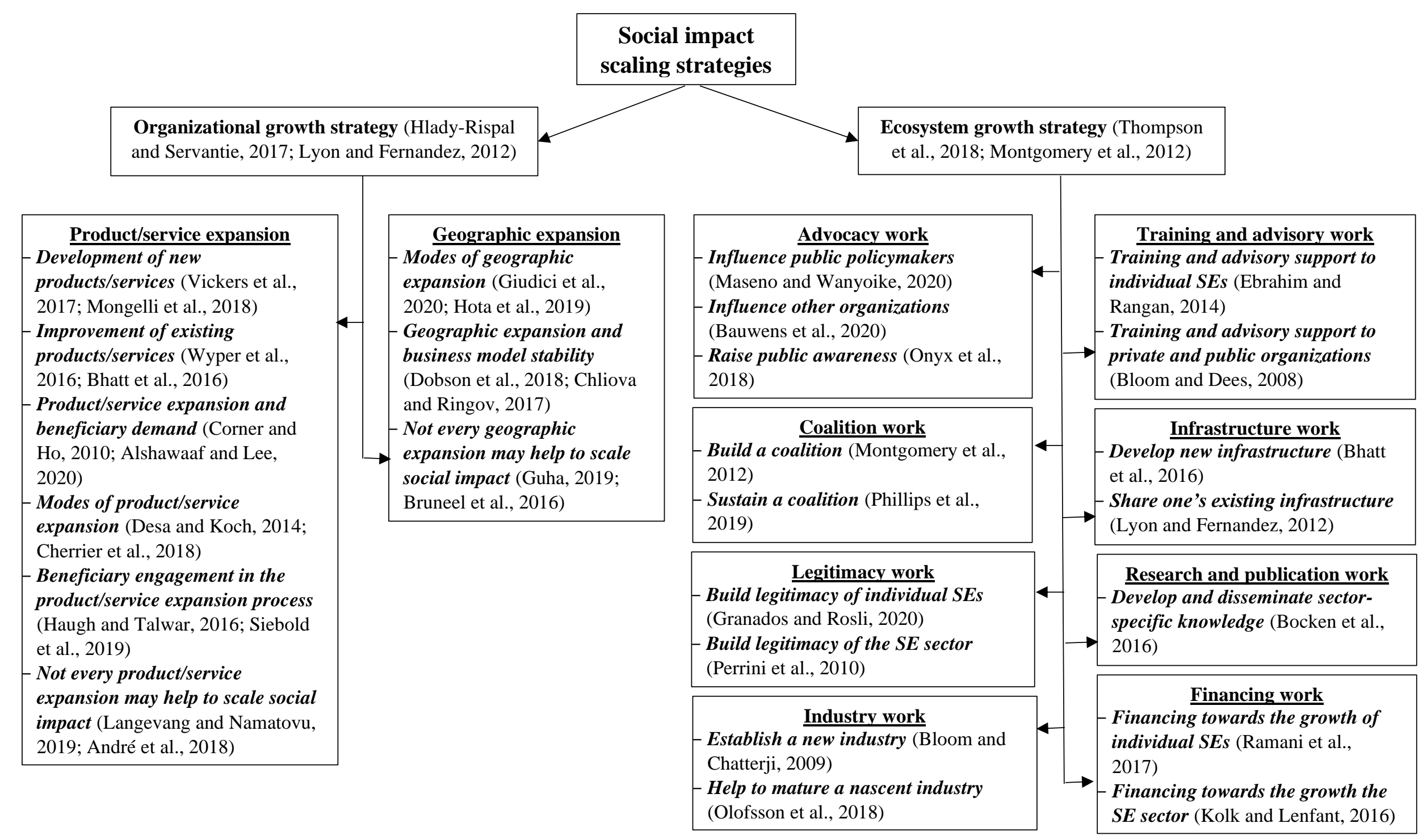

Figure 1. A summary of key insights into social impact scaling strategies in social enterprises (representative references are in the parentheses) 


\section{Scaling social impact through organizational growth strategy}

This section discusses key insights into scaling social impact through organizational growth strategy in SEs, as identified in the literature.

\subsection{Product/service expansion}

A major activity that SEs pursue as part of organizational growth strategy to scale their social impact is to expand their products/services to address varying needs of targeted beneficiaries. Here, products/services are used as an umbrella term to refer to a SE's products, services, activities, initiatives, and programs through which it addresses the targeted social problems.

\subsubsection{Development of new products/services. Developing new products/services, and thereby} addressing unmet social needs, is a popular path to scale social impact (Vickers et al., 2017; Vickers and Lyon, 2014). Research shows that SEs scale their social impact by developing new products/services that are related to their existing products/services. For example, Grameen Bank expanded its microcredit program by introducing new but related products, such as basic loans, flexible loans, saving accounts, pension plans, and loan insurance (Yunus, 2007; Grameen Bank, 2016; Alvord et al., 2004). Related products/services are developed to offer a "complete package" that can address widely distributed needs of beneficiaries, helping to improve the overall quality of life of beneficiaries (Mongelli et al., 2018; Roy and Karna, 2015; Auvinet and Lloret, 2015; Kodzi Jr., 2015). However, by developing related products/services to serve its beneficiaries, a SE positions itself within a single industry (e.g., the renewable energy industry), making itself more susceptible to the survival threat resulting from a major change in the focal industry (e.g., government policy change and an overall slowdown of industry-specific economic activities) (Hillman et al., 2018; Barraket and Loosemore, 2018).

SEs also scale their social impact by developing new but unrelated products/services. For example, to serve its beneficiaries, BRAC - a Bangladesh-based SE - introduced several new 
products but in unrelated sectors, such as health, education, financial services, agriculture, etc. (Alvord et al., 2004). The development of unrelated products/services helps to cater to varying needs of different beneficiary groups, and thus, facilitates a rapid increase in a SE's beneficiary base (Langevang and Namatovu, 2019; Bocken et al., 2016). Furthermore, by developing unrelated products/services to scale its social impact, a SE operates in multiple industries, and thus, is more protected against the survival threat resulting from major changes in an industry (Powell et al., 2019). However, developing unrelated products/services adds extra complexity to a SE's operations, and SEs that lack sufficient resources (e.g., financial and human) may struggle to provide a quality service to their beneficiaries (Uvin et al., 2000).

3.1.2 Improvement of existing products/services. SEs do not necessarily develop completely new products/services to scale their social impact. Improvement of existing products/services (e.g., the addition of new features into an existing product/service) also enables a SE to scale its social impact. Take the example of Transport for Tongue Limited (T4T), a SE that provides transport services in a rural community (that mostly comprises of retirees) in Scotland. After several months of its operations, T4T introduced new transportation routes as well as offering extended service hours in some of its existing routes to better serve community members making their weekend visits to city areas (Wyper et al., 2016). Thus, by improving its existing products/services to better serve its existing beneficiaries, a SE like T4T helps to increase the overall quality of life of its beneficiaries.

SEs also improve their existing products/services to serve new beneficiary groups, which is a cost-effective way to serve a larger beneficiary base. For example, Mahiti Infotech, an Indian SE, developed an open-source software, OurCrop, for monitoring and tracking the effectiveness of farming activities (e.g., crop procurement, inventory management, and marketing operations) (Bhatt et al., 2016). Initially, the original product served around 5,000 cotton farmers in a state in India. However, gradually, Mahiti developed several customized 
versions of OurCrop for different farmer groups (e.g., coffee growers, groundnuts and soya growers) in India as well as abroad to suit those organizations' operations, and thus, was serving over 100,000 farmers globally by 2015 (Bhatt et al., 2016).

3.1.3 Beneficiary demand. Research shows that, in most cases, SEs expand their products/services in response to the existing demand from beneficiaries (e.g., Desa and Koch, 2014; Uvin, 1995). This practice ensures a better product-beneficiary fit, since SEs can tailor their products/services to meet the beneficiaries' requirements (Corner and Ho, 2010). However, ensuring a product-beneficiary fit is not that straightforward; rather, it requires careful unpacking of beneficiaries' problems through deep immersion in their everyday lives (Vickers et al., 2017; Bhatt et al., 2016). When a SE aims to develop products/services that have strong demand in the specific community, investors and other stakeholders perceive the products/services as highly valuable and are more inclined to provide supports (Albert et al., 2016).

Instead of responding to the existing demand, at times, SEs also develop products/services to gradually create the demand for such a product/service among targeted beneficiaries. For example, BRAC experimented with a new service, "model ward", in a specific village in Bangladesh, although there was no explicit demand for the service at the time of its initiation in 2012 (May et al., 2014). The underlying idea of this new service (i.e., model ward) was to bring a village together to define their own vision of a model community in terms of various parameters (e.g., school enrolment, economic opportunities, and sanitary latrine availability) and then, work together to realize it (May et al., 2014). Although BRAC was not sure about this new service's success, it gradually created the demand for the service in that village and later delivered it to over 13,000 villages by 2014 (May et al., 2014). SEs appear to push a new product/service in the market when they anticipate that the new product/service, if successful, will have a significant positive impact on the lives of targeted beneficiaries (Khare and Joshi, 
2018; Alshawaaf and Lee, 2020). However, in this case, as products/services are developed in the absence of existing demand from targeted beneficiaries, there is a higher risk of nonacceptance of the products/services in the market, and thereby, a waste of resources expended on product/service development (Katre and Salipante, 2012; Bloom and Chatterji, 2009).

3.1.4 Modes of product/service expansion. While scaling social impact, a partnership-based mode of product/service expansion is a popular one, where a SE expands its products/services in partnership with other organizations (e.g., Westley et al., 2014; Wang et al., 2016). For example, Naandi, an India SE, partnered with private organizations, state governments, and local authorities to develop water treatment plants to provide safe drinking water to rural villages in India (Desa and Koch, 2014). A partnership-based mode of product/service expansion leverages multiple organizations' expertise and resources (Gillett et al., 2019; Corner and Ho, 2010; Shier and Handy, 2020). Thus, it helps increase the overall quality of the products/services developed (Henry, 2015). However, as multiple firms often have different agendas, products/services developed through a partnership-based mode may not be wellaligned with the focal SE's mission (Le Ber and Branzei, 2010; Berger et al., 2004; Peerally et al., 2019).

Research also shows that, at times, SEs adopt a more organic mode of product/service expansion to scale their social impact - that is, they expand products/services on their own (e.g., Bauwens et al., 2020; Lyon and Fernandez, 2012). SEs tend to adopt an organic mode of product/service expansion when they have sufficient resources (e.g., money and knowledgeable staff members) to develop "good enough" products/services by themselves (Bhatt et al., 2016; Olofsson et al., 2018), when there is no suitable organizations or individuals to collaborate (Khare and Joshi, 2018; Langevang and Namatovu, 2019), and/or when they want to protect the technical "know-how" for competition reasons (Cherrier et al., 2018). However, because of the limitation that a single organization may have, an organic mode takes 
a long time to bring products/services to the market, and thus, may slow the process of addressing targeted social problems (Palomares-Aguirre et al., 2018).

3.1.5 Beneficiary engagement. While expanding products/services to scale their social impact, SEs generally involve their target beneficiaries in the process (e.g., Pless and Appel, 2012; Ramani et al., 2017). Scholars show that engaging beneficiaries in the product/service development process help develop trust between the focal SE and its beneficiaries (Bhatt and Altinay, 2013; Sengupta et al., 2020). This, in turn, facilitates greater acceptance and implementation of the product/service in the community (Haugh and Talwar, 2016; Vestrum, 2014; Siebold et al., 2019).

However, in the case of work integration SEs (WISEs) that mainly provide employment or workplace training opportunities to disadvantaged people (Battilana et al., 2015; Leung et al., 2019; Ramus and Vaccaro, 2017; Easter and Conway Dato-On, 2015), researchers note the importance of selectively engaging beneficiaries in various tasks. On the one hand, involving beneficiaries in tasks that require higher skills than beneficiaries' skills can result in developing sub-optimal products/services and lower productivity (Powell et al., 2019), damaging the organization's business prospect, and thereby, impair the organization's ability to serve its beneficiaries in the future (Bruneel et al., 2016). On the other hand, engaging, for example, a disabled beneficiary in an unsafe task (e.g., operating a heavy machine) would represent a major occupational health and safety risk for the beneficiary (Loosemore, 2015).

3.1.6 Potential unintended consequences. Although product/service expansion enables SEs to scale their social impact by addressing targeted social problems, scholars note that this is not always the case. Indeed, developing products/services that are incompatible with a SE's mission or context can lead to business failure in terms of lack of investors, loss of relationship with key stakeholders, and waste of resources (Katre and Salipante, 2012; Austin et al., 2006). 
SEs that develop unrelated (rather than related) products/services to scale their social impact are more susceptible to the risk of product/service incompatibility, since it is more challenging to tie unrelated products/services together (Bacq et al., 2015; Di Domenico et al., 2010). Take the example of Gulu Youth Development Association (GYDA), an Uganda-based SE that mainly provides vocational training to the most vulnerable young people. When GYDA ventured into a new service, namely, motorbike taxi services, the new service appeared to be incompatible with GYDA's capacity and context (Langevang and Namatovu, 2019). Consequently, GYDA had to terminate its motorbike taxi services within six months of its operation, which resulted in a waste of its limited resources (Langevang and Namatovu, 2019).

Researchers also note that developing products/services that do not address a specific social need in a better way than the current alternative may not be helpful in scaling social impact. For example, a SE is not actually making a social impact by providing fresh drinking water to underprivileged people when its product offerings (e.g., product quality and price) are similar to that of the existing commercial organizations (André et al., 2018). Therefore, to scale its social impact, a SE needs to expand its products/services to address a specific social need in a better way than the existing alternatives do (André et al., 2018; Auvinet and Lloret, 2015; Kickul et al., 2018).

\subsection{Geographic expansion}

The second major activity that SEs pursue as part of organizational growth strategy to scale their social impact is to expand their geographic coverage to reach a larger number of beneficiaries.

3.2.1 Modes of geographic expansion. Forming some sort of partnership with other organizations (i.e., a partnership-based mode) to reach beneficiaries in wider geographic areas is a popular geographic expansion mode (Parris and McInnis-Bowers, 2014; Bocken et al., 
2016; Shrimali et al., 2011). Within this partnership-based mode of geographic expansion, franchising is a common arrangement, where the original SE (the franchisor) sells the right to market products/services under its name and using its practices to a local SE (the franchisee) (Tracey and Jarvis, 2007; Bradach, 2003). For example, Drishtee, an Indian SE whose mission is to empower rural communities by providing information technology goods and services, adopted a franchising arrangement to expand its operations in hundreds of villages in India (Desa and Koch, 2014). Although a franchising arrangement offers rapid geographic expansion in a cost-effective way (Beckmann and Zeyen, 2014), the original SE (the franchisor) may not reap the full potential of such an arrangement due to its lack of expertise in selecting and managing franchisees and much control over the local SE's operations (Krzeminska and Zeyen, 2017; Giudici et al., 2020).

In addition to a franchising arrangement, the partnership-based geographic expansion also takes other forms, such as licensing, joint ventures, micro-assignments, etc. (Dobson et al., 2018; Parris and McInnis-Bowers, 2014; Hota et al., 2019). Despite their various forms, partnership-based geographic expansion facilitates quicker and greater reach to beneficiaries due to local partners' higher degree of local embeddedness and localized knowledge (Klein et al., 2020; Rangan and Gregg, 2019). However, finding suitable local partners is always a challenging endeavor (Pless and Appel, 2012; Zhao and Han, 2020).

Research also shows that many SEs expand their operations to a new geographic market through an organization-owned mode - that is, by opening their own local branches. For example, $\mathrm{ABC}$, an Indian SE that delivers science-based education and experiential learning to school-aged children, expanded to over 19 states in India through replicating the educational program on its own (Guha, 2019). The organization-owned mode is particularly suitable when successful geographic expansion depends on tight quality control and specific practices and knowledge that are not explicitly documented and readily communicated (Dees et al., 2004). 
However, it demands a greater investment of resources and a higher degree of central coordination (Smith et al., 2016; Smith and Stevens, 2010).

3.2.2 Business model stability. Scholars show that, in most instances, SEs expand their geographic coverage with a proven business model (e.g., Bradach, 2003; Dees et al., 2004). Here, a SE such as Aravind Eye Hospital first aims to systematically develop and fine-tune its business model in a limited geographic area (Ebrahim and Rangan, 2014). Once it has developed a successful business model, it then replicates the model to wider geographic markets (Chliova and Ringov, 2017). A proven business model facilitates rapid geographic expansion, especially when different geographic markets share common features (Ebrahim and Rangan, 2014; Rangan and Gregg, 2019). However, a copy-and-paste approach to replicating a proven business model in a new geographic area may not be successful (Cannatelli, 2017). For example, SEWA's, an Indian SE, business model was highly successful in increasing its membership base in the Gujarat region, but was far from successful when the exact model was replicated in other nearby regions because of the subtle socio-cultural differences between Gujarat and other nearby regions (Roy and Karna, 2015). This suggests that, while expanding their operations to a new geographic area, SEs need to remain open and vigilant to refine their existing, proven business models to better reflect the important subtleties of the new area.

Although geographic expansion with a proven business model is a popular phenomenon, a few recent studies show that some SEs also expand their operations to new geographic markets with an unproven business model. For example, ViaVia Travellers Café (ViaVia), a Belgiumbased SE, deliberately expanded its operations to several locations across four continents with an unproven business model (Dobson et al., 2018: 4558). An unproven business model remains highly flexible to change and open to experimentation, and thus, has greater potential to capture the local market dynamics in an uncertain environment (Dobson et al., 2018; Perrini et al., 2010). 
Recent research also shows that, at times, the decision to expand geographic coverages with an unproven business model is less deliberate and more "accidental" in nature to capitalize on an unexpected opportunity to create significant social impact. For example, Tiempo de Juego (TJ), a Colombian SE that aims to improve the wellbeing of poor and vulnerable neighborhoods, expanded its operations to a new neighborhood with an unproven business model to seize a sudden opportunity (e.g., strong support from a local stakeholder group) that had the potential to change a greater number of lives of vulnerable teenagers (Hlady-Rispal and Servantie, 2017).

\subsubsection{Potential unintended consequences. Although geographic expansion enables a SE to scale} its social impact by serving larger numbers of beneficiaries, this may not always be the case. Researchers note that geographic expansion with "inappropriate" local partners may backfire. For example, when a SE provides its services to distant locations through a local partner, the local partner may exploit the underprivileged beneficiaries as well as the focal SE's brand image (Beckmann and Zeyen, 2014). Thus, geographic expansion with inappropriate local partners may actually increase (rather than decrease) the suffering of target beneficiaries (Huybrechts et al., 2017; Guha, 2019).

Scholars also point out that unthoughtful geographic expansion may impair a SE's overall ability to serve its beneficiaries in the long run. This is because serving a large number of beneficiaries in dispersed geographic locations increases significant complexity (e.g., reconfiguration of organizational structure) in a SE's operations (Battilana et al., 2015; Walske and Tyson, 2015). Many SEs do not have the necessary resources and expertise to manage larger geographic operations (Becker et al., 2017; Scheuerle and Schmitz, 2016). In such cases, ineffectiveness and inefficiency may arise in a SE's operations, which may compromise the quality of services delivered to beneficiaries (Langevang and Namatovu, 2019; Bruneel et al., 2016; Ormiston and Seymour, 2011). 
Furthermore, while geographic expansion provides SEs with an opportunity to generate higher earned-income (Bacq and Eddleston, 2018), serving only those beneficiaries who can afford to pay for products/services (i.e., not serving those who cannot afford to pay) may not create a desired social impact (Bailis et al., 2009; Shrimali et al., 2011; Wolf and Mair, 2019). Indeed, researchers note that geographic expansion building on a "number" principle rather than a "caring" principle contradicts with the fundamental values underlying the establishment of SEs (André and Pache, 2016; Blundel and Lyon, 2015; Ometto et al., 2019).

\section{Scaling social impact through ecosystem growth strategy}

This section discusses key insights into scaling social impact through ecosystem growth strategy in SEs, as identified in the literature.

In business, the concept of ecosystem generally implies a set of attributes (e.g., networks, investment capital, mentors, infrastructure, policy and governance, etc.) that collectively create a supportive environment for a business to thrive (Spigel and Harrison, 2018; Spigel, 2017). The attributes underlying a supportive business ecosystem are produced and re-produced by a variety of organizations and individuals (McMullen, 2018; Zahra and Nambisan, 2012). In line with this, a SE ecosystem comprises a set of attributes that create a conducive environment for SEs to flourish (Bloom and Dees, 2008; VanSandt et al., 2009; Thompson et al., 2018). Researchers show that, apart from growing the organizational size, SEs also scale their social impact by indirectly addressing social problems on a bigger scale by growing and/or sustaining a supportive SE ecosystem through several major activities, as will be detailed below (Bradach, 2010; Montgomery et al., 2012; Elsayed, 2018; Westley et al., 2014). 


\subsection{Advocacy work}

Advocacy constitutes an important attribute in a SE ecosystem (Bradach, 2010; Grant and Crutchfield, 2007). A major form of a SE's advocacy work is to organize a campaign by coordinating other grassroots alliances, organizations, and/or individuals to influence public policymakers in favor of a specific social problem (Uvin et al., 2000; Bloom and Smith, 2010; Maseno and Wanyoike, 2020). For example, Self-Help, a USA-based SE, organized several individuals, business groups (e.g., banks, homebuilders), and activist organizations to advocate for an anti-predatory lending law to improve the financial wellbeing of poor people by protecting them from practices, such as unfair refinance deals and "payday lending" (Bloom and Dees, 2008).

Furthermore, a SE's advocacy work does not necessarily focus on influencing public policymakers; rather, it also focuses on influencing other organizations to adopt certain products, services, or business models to address a certain social problem on a larger scale. For example, Ecopower, a Belgium-based cooperative that provides renewable energy-related services to address energy poverty, undertook several advocacy-related activities to influence other social entrepreneurs to replicate its business model throughout the country, and thereby addressing energy poverty at a national scale (Bauwens et al., 2020). Similarly, SEs also undertake their advocacy work in the form of raising greater public awareness about a specific social problem and/or the availability of certain products regarding a certain social problem (Onyx et al., 2018; Uvin et al., 2000). However, researchers note that, at times, SEs' advocacy work can trigger hostile behavior from the government, which can significantly jeopardize their operations (Elsayed, 2018; Darby, 2016; Islam, 2020b).

\subsection{Coalition work}

Another crucial attribute of a SE ecosystem is the presence of a coalition, defined as a formal or informal network of various individuals and/or organizations, which aims to tackle complex 
social problems collaboratively (Dees et al., 2004; Salignac et al., 2018). Scholars show that some SEs take a more leadership role and build a new coalition from scratch (Becker et al., 2017; Perrini et al., 2010), while others take a more participant role and help to sustain a coalition by participating in regular activities that underlie the coalition (Granados and Rosli, 2020; Phillips et al., 2019). By helping to build/sustain a coalition, a SE facilitates the sharing and exchanging of good practices of addressing various social problems (Lyon and Fernandez, 2012; Hillman et al., 2018). Such a coalition also aids social entrepreneurs to validate their business models and increase their confidence in implementing social mission (Granados and Rosli, 2020) and obtain more collaboration opportunities (Montgomery et al., 2012). Researchers also show that a coalition serves as a platform to pool resources and expertise from various SEs, which are then used to better compete with well-resourced commercial organizations; for example, to win large public and/or private contracts (Phillips et al., 2019; Gillett et al., 2019; Saripalli et al., 2019).

\subsection{Industry work}

SEs also scale their social impact through their industry work, which takes several forms. Researchers show that some SEs help to address a certain social problem by establishing a new industry. Take the example of Self-Help, a USA-based SE. By observing the very limited access of low-income people to the mainstream home mortgage market in the USA, Self-Help established a secondary mortgage market for low-income people in 1998 (Bloom and Chatterji, 2009). To do so, it innovatively leveraged its own resources as well as those of the Ford Foundation, Fannie Mae, and several other financial institutions (Bloom and Chatterji, 2009). Although establishing a new industry takes considerable expertise and resources (e.g., money, time, and effort), such work can potentially be a game-changer, significantly improving the lives of missions of beneficiaries (Alvord et al., 2004). 
A SE's industry work also takes place in the form of developing new products, services, and/or practices, which help to mature a nascent industry. For example, BeauVent, a Belgium-based SE, experiments and develops new technologies and innovative practices regarding energy efficiency and energy savings in the renewable energy industry, and then openly shares them with other organizations, mainly to flourish the renewable energy industry as a whole, and thereby addresses energy poverty at a much broader level (Bauwens et al., 2020). Similarly, AlphaEl, a Scandinavian SE that produces and supplies renewable energy in rural areas, developed an innovative practice, namely, dynamic pricing contracts, to reduce consumers' electricity costs, which has become a standard practice in the renewable energy industry (Olofsson et al., 2018).

\subsection{Training and advisory work}

Many SEs scale their social impact by providing training and advisory support to other SEs to help them effectively run their operations (Lyon and Fernandez, 2012). For example, Aravind Eye Hospital offers a training and advisory program where hundreds of administrators and healthcare workers from 43 countries come to learn the "Aravind management model", which is built on low-cost and high-quality patient care systems (Ebrahim and Rangan, 2014). Thus, through its training and advisory work towards other SEs, Aravind Eye Hospital contributes towards better addressing vision care-related problems of underprivileged people on a global scale, which would not have been possible through organizational growth alone.

Researchers also show that some SEs contribute to the development of the SE sector as a whole through their training and advisory work towards private and public organizations. For example, a leading Australian SE in the construction industry provides training and advisory support to private organizations in the same industry to help them develop and implement their "social procurement" policy, which aims to purchase a certain dollar amount of products/services from SEs (Barraket, 2020). In this case, through its training and advisory 
work towards private organizations, the focal SE is indirectly creating more earned-income opportunities for SEs as a whole. Similarly, Bloom and Dees (2008) show that Self-Help, a US-based SE, provided training and advisory support to several state governments in the USA to help them develop new laws to prevent "loan sharks" from exploiting poor people.

\subsection{Infrastructure work}

The presence of sufficient infrastructure is a major attribute of an effective SE ecosystem (Warnecke, 2018; Hoogendoorn et al., 2019). Researchers show that some SEs scale their social impact by developing new infrastructure necessary for the effective functioning of individual SEs and the SE sector as a whole. For example, Mahiti Infotech, an Indian SE, develops and freely distributes a selection of software, namely, "NGO-In-A-Box", along with their user manual (Bhatt et al., 2016). Mahiti does so to strengthen the information and communication technology (ICT) infrastructure of the SE sector in India and beyond, and thereby, help better manage the operations of organizations (e.g., other SEs, funders) that are committed to making a social change (Bhatt et al., 2016).

Furthermore, some SEs also help the effective functioning of other SEs by sharing their existing infrastructure with other SEs that cannot afford such infrastructure. For example, Ossington Nursery, a UK-based SE, allows other SEs rent-free use of its office spaces and premises to run workshops and other functions and events (Lyon and Fernandez, 2012). Without receiving such support from Ossington Nursery, these SEs might not have implemented their social mission smoothly.

\subsection{Legitimacy work}

Legitimacy constitutes another major element of a supportive SE ecosystem, especially because of the infancy of the SE sector (Garrigós Simón et al., 2017; Smith and Stevens, 2010; Costa et al., 2011; Molecke and Pinkse, 2017). Researchers show that some SEs do their 
legitimacy work towards other SEs, especially the younger and less-reputed ones, by helping them gain and maintain the legitimacy necessary to survive and grow. For example, a leading Australian SE in the construction industry helped several young SEs gain the legitimacy required to bid for private and public contracts by helping them measure and evaluate their social impact (Barraket, 2020). Similarly, Granados and Rosli (2020) show that, in the UK, a few reputed SEs helped to build the legitimacy of other less-reputed SEs in the market by promoting their products/services to potential clients and partners.

Furthermore, some SEs create social value by building the legitimacy of the SE sector as a whole through promoting the contribution that the SE sector is making in a specific community, region, or country (Perrini et al., 2010; Mason, 2012). This fosters community buy-in to the activities of SEs (Warnecke, 2018; Haugh and Talwar, 2016). Although such a community buy-in is important for all SEs (Sardana et al., 2019; Di Domenico et al., 2010), it is particularly important for SEs whose social mission (e.g., promoting immigrant's welfare) is stigmatized in a specific community (Tracey and Phillips, 2016).

\subsection{Research and publication work}

Because of their crucial role in developing and disseminating valuable knowledge, research and publication are considered to be the lifeblood of an entrepreneurial ecosystem (Spigel, 2017). Many SEs create social impact by developing and disseminating sector-specific knowledge (Dees et al., 2004). Take the example of KaBOOM!, a USA-based SE that fosters the development of safe and active play opportunities for kids. Through its years of research, KaBOOM! has developed an innovative and successful program called "Play Everywhere" to turn non-traditional play spaces (e.g., bus stops, laundromats) into creative outlets for play (KaBOOM!, 2019). The organization publishes the freely accessible "Play Everywhere Playbook" on its website for other organizations to readily access and adopt the program, and thereby addresses the issue of safe and active play opportunities for kids on a global scale. 
Indeed, by conducting research, for example, on the behaviors and needs of target beneficiaries as well as publishing such research in an easily accessible way for other organizations, SEs help to develop and implement innovative products/services to better address targeted social problems on a larger scale (Weerawardena et al., 2010; Bloom and Chatterji, 2009). While bigger SEs (e.g., BRAC and Aravind Eye Hospital) usually undertake large-scale research and publication work due to their dedicated research and publication units (Bocken et al., 2016), smaller SEs develop and disseminate important knowledge through publishing books and smaller case studies (Mair et al., 2012; Kolk and Lenfant, 2016). A SE's such work can also inspire budding entrepreneurs to pursue a social entrepreneurial career (Bacq et al., 2016; Katre and Salipante, 2012).

\subsection{Financing work}

Availability of financial resources is another crucial element of a supportive SE ecosystem (Walske and Tyson, 2015; Scheuerle and Schmitz, 2016; Meyskens and Bird, 2015; Lehner and Nicholls, 2014). Researchers show how SEs scale their social impact through their financing work. Some SEs invest equity capital in other SEs to support their growth, where the investment is made either directly or through a consortium of other individuals/organizations (Bhatt and Ahmad, 2017; Ramani et al., 2017). Instead of providing equity capital, some SEs also do financing work in the form of making donations and grants to other SEs. For example, AlphaEl, a Scandinavian SE, donates the majority of its profit to other organizations that are committed to addressing various social problems (Olofsson et al., 2018). A SE's financing work towards other SEs also takes the form of offering service contracts or sub-contracts to supplier SEs, making purchase guarantees from supplier SEs, and giving an interest-free and extended credit facility to customer SEs (Wilson and Post, 2013; Meyskens et al., 2010; Spieth et al., 2019; Sydow et al., 2020). 
However, a SE's financing work does not focus on individual SEs only; rather, it also focuses on the SE sector as a whole. For example, Coffee Rwanda, a Rwanda-based SE, donates its profit for the development of various infrastructure to strengthen the supply chain operations of the SE sector in Rwanda (Kolk and Lenfant, 2016). Indeed, researchers show that many SEs help address certain social problems on a larger scale through funding the development and sustainment of several attributes (e.g., to build a coalition and to organize an advocacy campaign) of the broader SE ecosystem in which they operate (Warnecke, 2018; Thompson et al., 2018; Powell et al., 2019).

\section{Discussion}

The objective of this paper is to provide a comprehensive picture of scaling social impact through organizational growth strategy and ecosystem growth strategy in SEs. The review shows that while scaling social impact, organizational growth strategy has remained a popular one through which SEs directly address targeted social problems on a large scale. A major activity under organizational growth strategy is product/service expansion, which takes in the form of the development of related and unrelated products/services as well as the improvement of existing products/services. While, in most cases, products/services are developed in response to existing beneficiary demand, they are also developed to gradually create their demand among targeted beneficiaries. The second major activity under organizational growth strategy is geographic expansion. In most cases, geographic expansion takes place with a proven business model. However, SEs also expand their geographic coverage with an unproven business model, especially when there is high uncertainty in the target market and when an unexpected opportunity arises to create significant social impact. That said, both product/service expansion and geographic expansion can create potential unintended consequences, suggesting that SEs need to be mindful of them while scaling their social impact. 
In contrast to organizational growth strategy, ecosystem growth strategy focuses on scaling social impact by indirectly addressing social problems through growing and/or sustaining a supportive SE ecosystem. While scaling social impact through ecosystem growth strategy, SEs pursue eight major activities (e.g., advocacy work, coalition work, etc.). At times, these activities focus on supporting the growth of individual SEs, whereas, at other times, they focus on facilitating the growth of the SE sector as a whole. Ultimately, all these activities aim to better address various social problems on a much broader scale, which cannot be achieved through organizational growth strategy alone.

\section{Future research opportunities}

While previous research has significantly advanced our knowledge on strategies/paths for scaling social impact, several areas have remained underexplored or undertheorized. Building on prior work, this paper now presents several promising avenues of future research.

\subsection{Different types of product/service expansion}

Recent research (e.g., Langevang and Namatovu, 2019; Bocken et al., 2016) shows how SEs scale their social impact by developing related as well as unrelated products/services. However, several questions have remained largely unanswered. For example, when should scaling social impact by developing related products/services get preference over unrelated products/services, and vice-versa?

Furthermore, although existing research (e.g., Vickers et al., 2017; Bauwens et al., 2020) has addressed the upsides of demand-driven product/service expansion, its downsides concerning scaling social impact are rarely discussed. Also, little systematic research exists on the antecedents, challenges, processes, and consequences of demand-creation product/service expansion as a means to scale social impact. 


\subsection{Different variants of geographic expansion}

Most research in the area of partnership-based geographic expansion has focused on one form of partnership, namely, a franchising arrangement (e.g., Giudici et al., 2020; Krzeminska and Zeyen, 2017). More in-depth research is needed to depict a comparative account of various forms (e.g., franchising, joint ventures, and micro-assignments) of partnership-based geographic expansion about scaling social impact in a specific context.

Furthermore, recent research (Dobson et al., 2018) shows that a SE can expand its operations in some locations through an organization-owned mode (i.e., by opening its own branches), and in other areas through a partnership-based mode. However, our understanding is limited about whether the simultaneous use of multiple modes of geographic expansion creates any unique challenges for a SE concerning scaling social impact, and if yes, how a SE addresses such challenges.

\subsection{Downsizing social enterprises}

An exciting and promising future research area is to understand issues around the relationship between downsizing a SE and scaling social impact. To date, upsizing the organization (e.g., geographic expansion and product/service expansion) as a means to scale social impact is prevalent in the literature (e.g., Powell et al., 2019; Hillman et al., 2018). However, a few studies (Austin et al., 2006; Uvin et al., 2000) note that some SEs do deliberately downsize their operations (e.g., stop offering certain products/services and stop serving certain geographic areas) in order to, for example, better focus on their core strengths. Unfortunately, we know little about a SE's decision-making process regarding when and how to downsize its operations as far as the scaling of social impact is concerned. 


\subsection{Choosing the most effective impact scaling strategy}

While existing research (e.g., Guha, 2019; Hota et al., 2019; Alshawaaf and Lee, 2020) shows how SEs pursue different strategies to scale their social impact, much more work remains to be done in this area. For example, although there are eight major activities under ecosystem growth strategy, a SE is unlikely to pursue all of them because of resource constraints (e.g., money, staff, and time). Therefore, future research could investigate how a SE decides which activity should be chosen over others to achieve higher social impact in a specific context. Also, recent research (Islam, 2020b) shows that, at times, a specific social impact scaling strategy (e.g., ecosystem growth strategy) can create unintended consequences in SEs. Future research could investigate how to avoid or mitigate the potential unintended consequences resulting from different impact scaling strategies.

Furthermore, most research on SEs has examined organizational growth strategy and ecosystem growth strategy separately (e.g., Chliova and Ringov, 2017; Cherrier et al., 2018; Thompson et al., 2018). As a result, we know little about, for example, whether and to what extent certain activities under organizational growth strategy are compatible or incompatible with certain activities under ecosystem growth strategy.

\section{Conclusion}

The current paper conducts a systematic review to provide a better understanding of organizational growth strategy and ecosystem growth strategy as a means to scale social impact in SEs. The review reveals that while scaling social impact through organizational growth strategy, SEs pursue two major activities - product/service expansion and geographic expansion. In contrast, while scaling social impact through ecosystem growth strategy, SEs undertake eight major activities - advocacy work, coalition work, industry work, training and 
advisory work, infrastructure work, legitimacy work, research and development work, and financing work. Key insights into each of these major activities are identified and discussed. This review has also highlighted some limitations, risks, or potential unintended consequences of various social impact scaling strategies, suggesting that SEs need to be mindful of them.

This paper has also presented several promising future research areas concerning social impact scaling in SEs. These promising research areas are different types of product/service expansion, different variants of geographic expansion, downsizing SEs, and choosing the most effective impact scaling strategy. In addition to contributing to the theory of SEs, future research in these areas could significantly contribute to the practice of SEs, since these are some important issues that SEs need to tackle while scaling social impact. The current paper also encourages researchers to seriously take local realities and contexts into account while examining the phenomenon of scaling social impact in SEs. This could help to identify the boundary conditions of different social impact scaling strategies in SEs. 


\section{References}

Albert LS, Dean TJ and Baron RA (2016) From social value to social cognition: How social ventures obtain the resources they need for social transformation. Journal of Social Entrepreneurship 7: 289-311.

Alshawaaf N and Lee SH (2020) Business model innovation through digitisation in social purpose organisations: A comparative analysis of Tate Modern and Pompidou Centre. Journal of Business Research in press: 1-12.

Alvord SH, Brown LD and Letts CW (2004) Social entrepreneurship and societal transformation: An exploratory study. The Journal of Applied Behavioral Science 40: 260-282.

André K, Cho CH and Laine M (2018) Reference points for measuring social performance: Case study of a social business venture. Journal of Business Venturing 33: 660-678.

André K and Pache AC (2016) From caring entrepreneur to caring enterprise: Addressing the ethical challenges of scaling up social enterprises. Journal of Business Ethics 133: 659675.

Austin J, Stevenson H and Wei-Skillern J (2006) Social and commercial entrepreneurship: Same, different, or both? Entrepreneurship Theory and Practice 30: 1-22.

Australian Business Deans Council (2019) The 2019 ABDC Journal Quality List.

Auvinet C and Lloret A (2015) Understanding social change through catalytic innovation: Empirical findings in Mexican social entrepreneurship. Canadian Journal of Administrative Sciences 32: 238-251.

Bacq S and Eddleston KA (2018) A resource-based view of social entrepreneurship: How stewardship culture benefits scale of social impact. Journal of Business Ethics 152: $589-611$ 
Bacq S, Hartog C and Hoogendoorn B (2016) Beyond the moral portrayal of social entrepreneurs: An empirical approach to who they are and what drives them. Journal of Business Ethics 133: 703-718.

Bacq S, Ofstein LF, Kickul JR, et al. (2015) Bricolage in social entrepreneurship: How creative resource mobilization fosters greater social impact. International Journal of Entrepreneurship and Innovation 16: 283-289.

Bailis R, Cowan A, Berrueta V, et al. (2009) Arresting the killer in the kitchen: The promises and pitfalls of commercializing improved cookstoves. World Development 37: 16941705.

Barraket J (2020) The role of intermediaries in social innovation: The case of social procurement in australia. Journal of Social Entrepreneurship 11: 194-214.

Barraket J and Loosemore M (2018) Co-creating social value through cross-sector collaboration between social enterprises and the construction industry. Construction Management and Economics 36: 394-408.

Battilana J, Sengul M, Pache AC, et al. (2015) Harnessing productive tensions in hybrid organizations: The case of work integration social enterprises. Academy of Management Journal 58: 1658-1685.

Bauwens T, Huybrechts B and Dufays F (2020) Understanding the diverse scaling strategies of social enterprises as hybrid organizations: The case of renewable energy cooperatives. Organization and Environment 33: 195-219.

Becker S, Kunze C and Vancea M (2017) Community energy and social entrepreneurship: Addressing purpose, organisation and embeddedness of renewable energy projects. Journal of Cleaner Production 147: 25-36. 
Beckmann M and Zeyen A (2014) Franchising as a strategy for combining small and large group advantages (logics) in social entrepreneurship: A Hayekian perspective. Nonprofit and Voluntary Sector Quarterly 43: 502-522.

Berger IE, Cunningham PH and Drumwright ME (2004) Social alliances: Company/nonprofit collaboration. California Management Review 47: 58-90.

Bhatt P and Ahmad AJ (2017) Financial social innovation to engage the economically marginalized: Insights from an Indian case study. Entrepreneurship \& Regional Development 29: 391-413.

Bhatt P, Ahmad AJ and Roomi MA (2016) Social innovation with open source software: User engagement and development challenges in India. Technovation 52-53: 28-39.

Bhatt P and Altinay L (2013) How social capital is leveraged in social innovations under resource constraints? Management Decision 51: 1772-1792.

Bloom PN and Chatterji AK (2009) Scaling social entrepreneurial impact. California Management Review 51: 114-133.

Bloom PN and Dees JG (2008) Cultivate your ecosystem. Stanford Social Innovation Review: 47- 53.

Bloom PN and Smith BR (2010) Identifying the drivers of social entrepreneurial impact: Theoretical development and an exploratory empirical test of SCALERS. Journal of Social Entrepreneurship 1: 126-145.

Blundel RK and Lyon F (2015) Towards a 'long view': Historical perspectives on the scaling and replication of social ventures. Journal of Social Entrepreneurship 6: 80-102.

Bocken NMP, Fil A and Prabhu J (2016) Scaling up social businesses in developing markets. Journal of Cleaner Production 139: 295-308.

Bradach JL (2003) Going to scale: The challenge of replicating social programs. Stanford Social Innovation Review: 18-25. 
Bradach JL (2010) Scaling impact. Stanford Social Innovation Review: 27-28.

Bruneel J, Moray N, Stevens R, et al. (2016) Balancing competing logics in for-profit social enterprises: A need for hybrid governance. Journal of Social Entrepreneurship 7: 263288.

Cannatelli B (2017) Exploring the contingencies of scaling social impact: A replication and extension of the SCALERS model. Voluntas 28: 2707-2733.

Chartered Association of Business Schools (2018) Academic Journal Guide.

Cherrier H, Goswami P and Ray S (2018) Social entrepreneurship: Creating value in the context of institutional complexity. Journal of Business Research 86: 245-258.

Chliova M and Ringov D (2017) Scaling impact: Template development and replication at the base of the pyramid. Academy of Management Perspectives 31: 44-62.

Corner PD and Ho M (2010) How opportunities develop in social entrepreneurship. Entrepreneurship Theory and Practice 34: 635-659.

Costa E, Ramus T and Andreaus M (2011) Accountability as a managerial tool in non-profit organizations: Evidence from Italian CSVs. Voluntas 22: 470-493.

Dacin MT, Dacin PA and Tracey P (2011) Social entrepreneurship: A critique and future directions. Organization Science 22: 1203-1213.

Darby S (2016) Dynamic resistance: Third-sector processes for transforming neoliberalization. Antipode 48: 977-999.

Dees JG, Anderson BB and Wei-Skillern J (2004) Scaling social impact: Strategies for spreading social innovations. Stanford Social Innovation Review 1: 24-32.

Desa G and Koch JL (2014) Scaling social impact: Building sustainable social ventures at the base-of-the-pyramid. Journal of Social Entrepreneurship 5: 146-174.

Di Domenico M, Haugh H and Tracey P (2010) Social bricolage: Theorizing social value creation in social enterprises. Entrepreneurship Theory and Practice 34: 681-703. 
Dobson K, Boone S, Andries P, et al. (2018) Successfully creating and scaling a sustainable social enterprise model under uncertainty: The case of ViaVia Travellers Cafés. Journal of Cleaner Production 172: 4555-4564.

Doherty B, Haugh H and Lyon F (2014) Social enterprises as hybrid organizations: A review and research agenda. International Journal of Management Reviews 16: 417-436.

Easter S and Conway Dato-On M (2015) Bridging ties across contexts to scale social value: The case of a Vietnamese social enterprise. Journal of Social Entrepreneurship 6: 320351.

Ebrahim A and Rangan VK (2014) What impact? A framework for measuring the scale and scope of social performance. California Management Review 56: 118-141.

Elsayed Y (2018) At the intersection of social entrepreneurship and social movements: The case of Egypt and the Arab spring. Voluntas 29: 819-831.

Garrigós Simón FJ, González-Cruz T and Contreras-Pacheco O (2017) Policies to enhance social development through the promotion of SME and social entrepreneurship: A study in the Colombian construction industry. Entrepreneurship \& Regional Development 29: 51-70.

Gillett A, Loader K, Doherty B, et al. (2019) An examination of tensions in a hybrid collaboration: A longitudinal study of an Empty Homes project. Journal of Business Ethics 157: 949-967.

Giudici A, Combs JG, Cannatelli BL, et al. (2020) Successful scaling in social franchising: The case of Impact Hub. Entrepreneurship Theory and Practice 44: 288-314.

Grameen Bank (2016) Annual Report

Granados ML and Rosli A (2020) 'Fitting in' vs. 'Standing out': How social enterprises engage with stakeholders to legitimize their hybrid position. Journal of Social Entrepreneurship 11: 155-176. 
Grant HM and Crutchfield LR (2007) Creating high-impact nonprofits. Stanford Social Innovation Review: 32-41.

Guha P (2019) Going to scale: A case study of an Indian educational NGO. Voluntas 30: 13651379.

Haugh HM and Talwar A (2016) Linking social entrepreneurship and social change: The mediating role of empowerment. Journal of Business Ethics 133: 643-658.

Henry C (2015) Doing well by doing good: Opportunity recognition and the social enterprise partnership. Journal of Social Entrepreneurship 6: 137-160.

Hillman J, Axon S and Morrissey J (2018) Social enterprise as a potential niche innovation breakout for low carbon transition. Energy Policy 117: 445-456.

Hlady-Rispal M and Servantie V (2017) Business models impacting social change in violent and poverty-stricken neighbourhoods: A case study in Colombia. International Small Business Journal 35: 427-448.

Hlady-Rispal M and Servantie V (2018) Deconstructing the way in which value is created in the context of social entrepreneurship. International Journal of Management Reviews 20: 62-80.

Hoogendoorn B, van der Zwan P and Thurik R (2019) Sustainable entrepreneurship: The role of perceived barriers and risk. Journal of Business Ethics 157: 1133-1154.

Hota PK, Mitra S and Qureshi I (2019) Adopting bricolage to overcome resource constraints: The case of social enterprises in rural India. Management and Organization Review 15: $371-402$.

Huybrechts B, Nicholls A and Edinger K (2017) Sacred alliance or pact with the devil? How and why social enterprises collaborate with mainstream businesses in the fair trade sector. Entrepreneurship \& Regional Development 29: 586-608. 
Islam SM (2020a) Towards an integrative definition of scaling social impact in social enterprises. Journal of Business Venturing Insights 13: 1-7.

Islam SM (2020b) Unintended consequences of scaling social impact through ecosystem growth strategy in social enterprise and social entrepreneurship. Journal of Business Venturing Insights 13: 1-6.

KaBOOM! (2019) Play Everywhere: Turning everyday places into playspaces. Available at: https://kaboom.org/play_everywhere.

Katre A and Salipante P (2012) Start-up social ventures: Blending fine-grained behaviors from two institutions for entrepreneurial success. Entrepreneurship Theory and Practice 36: 967-994.

Khare P and Joshi K (2018) Systems approach to map determinants of a social enterprise's impact: A case from India. Journal of Social Entrepreneurship 9: 31-51.

Kickul J, Griffiths M, Bacq S, et al. (2018) Catalyzing social innovation: Is entrepreneurial bricolage always good? Entrepreneurship \& Regional Development 30: 407-420.

Klein S, Schneider S and Spieth P (2020) How to stay on the road? A business model perspective on mission drift in social purpose organizations. Journal of Business Research in press: 1-14.

Kodzi Jr. ET (2015) The clash of missions: Juxtaposing competing pressures in South Africa's social enterprises. Journal of Social Entrepreneurship 6: 278-298.

Kolk A and Lenfant F (2016) Hybrid business models for peace and reconciliation. Business Horizons 59: 503-524.

Krzeminska A and Zeyen A (2017) A stewardship cost perspective on the governance of delegation relationships: The case of social franchising. Nonprofit and Voluntary Sector Quarterly 46: 71-91. 
Langevang $\mathrm{T}$ and Namatovu $\mathrm{R}$ (2019) Social bricolage in the aftermath of war. Entrepreneurship \& Regional Development 31: 785-805.

Le Ber MJ and Branzei O (2010) (Re)forming strategic cross-sector partnerships: Relational processes of social innovation. Business and Society 49: 140-172.

Lehner OM and Nicholls A (2014) Social finance and crowdfunding for social enterprises: A public-private case study providing legitimacy and leverage. Venture Capital 16: 271286.

Leung ZCS, Ho APY, Tjia LYN, et al. (2019) Social impacts of work integration social enterprise in Hong Kong - Workfare and beyond. Journal of Social Entrepreneurship 10: $159-176$.

Linnenluecke MK, Marrone M and Singh AK (2020) Conducting systematic literature reviews and bibliometric analyses. Australian Journal of Management 45: 175-194.

Loosemore M (2015) Building a new third construction sector through social enterprise. Construction Management and Economics 33: 724-739.

Lyon F and Fernandez H (2012) Strategies for scaling up social enterprise: Lessons from early years providers. Social Enterprise Journal 8: 63-77.

Mair J, Battilana J and Cardenas J (2012) Organizing for society: A typology of social entrepreneuring models. Journal of Business Ethics 111: 353-373.

Maseno M and Wanyoike C (2020) Social entrepreneurship as mechanisms for social transformation and social impact in East Africa: An exploratory case study perspective. Journal of Social Entrepreneurship in press: 1-26.

Mason C (2012) Isomorphism, social enterprise and the pressure to maximise social benefit. Journal of Social Entrepreneurship 3: 74-95.

May MA, Misiti AJ, Hussain I, et al. (2014) What does it take to scale social impact? Insights from South Asia. (accessed 02.08.19). 
McMullen JS (2018) Organizational hybrids as biological hybrids: Insights for research on the relationship between social enterprise and the entrepreneurial ecosystem. Journal of Business Venturing 33: 575-590.

Meyskens M and Bird L (2015) Crowdfunding and value creation. Entrepreneurship Research Journal 5: 155-166.

Meyskens M, Carsrud AL and Cardozo RN (2010) The symbiosis of entities in the social engagement network: The role of social ventures. Entrepreneurship \& Regional Development 22: 425-455.

Molecke G and Pinkse J (2017) Accountability for social impact: A bricolage perspective on impact measurement in social enterprises. Journal of Business Venturing 32: 550-568.

Mongelli L, Versari P, Rullani F, et al. (2018) Made in Carcere: Integral human development in extreme conditions. Journal of Business Ethics 152: 977-995.

Montgomery AW, Dacin PA and Dacin MT (2012) Collective social entrepreneurship: Collaboratively shaping social good. Journal of Business Ethics 111: 375-388.

Olofsson S, Hoveskog M and Halila F (2018) Journey and impact of business model innovation: The case of a social enterprise in the Scandinavian electricity retail market. Journal of Cleaner Production 175: 70-81.

Ometto MP, Gegenhuber T, Winter J, et al. (2019) From balancing missions to mission drift: The role of the institutional context, spaces, and compartmentalization in the scaling of social enterprises. Business and Society 58: 1003-1046.

Onyx J, Darcy S, Grabowski S, et al. (2018) Researching the social impact of arts and disability: Applying a new empirical tool and method. Voluntas 29: 574-589.

Ormiston J and Seymour R (2011) Understanding value creation in social entrepreneurship: The importance of aligning mission, strategy and impact measurement. Journal of Social Entrepreneurship 2: 125-150. 
Palomares-Aguirre I, Barnett M, Layrisse F, et al. (2018) Built to scale? How sustainable business models can better serve the base of the pyramid. Journal of Cleaner Production 172: 4506-4513.

Parris DL and McInnis-Bowers CV (2014) Social entrepreneurship questioning the status quo: Waste as a resource. Journal of Economic Issues 48: 359-366.

Peerally JA, De Fuentes C and Figueiredo PN (2019) Inclusive innovation and the role of technological capability-building: The social business Grameen Danone Foods Limited in Bangladesh. Long Range Planning 52: 1-24.

Perrini F, Vurro C and Costanzo LA (2010) A process-based view of social entrepreneurship: From opportunity identification to scaling-up social change in the case of San Patrignano. Entrepreneurship \& Regional Development 22: 515-534.

Phillips W, Alexander EA and Lee H (2019) Going it alone won't work! The relational imperative for social innovation in social enterprises. Journal of Business Ethics 156: $315-331$.

Pless NM and Appel J (2012) In pursuit of dignity and social justice: Changing lives through $100 \%$ inclusion - How Gram Vikas fosters sustainable rural development. Journal of Business Ethics 111: 389-411.

Powell M, Gillett A and Doherty B (2019) Sustainability in social enterprise: Hybrid organizing in public services. Public Management Review 21: 159-186.

Ramani SV, SadreGhazi S and Gupta S (2017) Catalysing innovation for social impact: The role of social enterprises in the Indian sanitation sector. Technological Forecasting and Social Change 121: 216-227.

Ramus T and Vaccaro A (2017) Stakeholders matter: How social enterprises address mission drift. Journal of Business Ethics 143: 307-322. 
Rangan VK and Gregg T (2019) How social entrepreneurs zig-zag their way to impact at scale. California Management Review 62: 53-76.

Roy K and Karna A (2015) Doing social good on a sustainable basis: Competitive advantage of social businesses. Management Decision 53: 1355-1374.

Saebi T, Foss NJ and Linder S (2019) Social entrepreneurship research: Past achievements and future promises. Journal of Management 45: 70-95.

Salignac F, Wilcox T, Marjolin A, et al. (2018) Understanding Collective Impact in Australia: A new approach to interorganizational collaboration. Australian Journal of Management 43: 91-110.

Sardana D, Bamiatzi V and Zhu Y (2019) Decoding the process of social value creation by Chinese and Indian social entrepreneurs: Contributory factors and contextual embeddedness. Management and Organization Review 15: 269-306.

Saripalli BS, Chawan V and Gunta S (2019) Empowering subsistence women entrepreneurs in India: Insights from Lijjat, Mulukanoor and MPWPCL. Society and Business Review 14: 71-92.

Scheuerle T and Schmitz B (2016) Inhibiting factors of scaling up the impact of social entrepreneurial organizations - A comprehensive framework and empirical results for Germany. Journal of Social Entrepreneurship 7: 127-161.

Sengupta S, Sahay A and Hisrich RD (2020) The social - market convergence in a renewable energy social enterprise. Journal of Cleaner Production 270: 1-15.

Shepherd DA, Williams TA and Patzelt H (2015) Thinking about entrepreneurial decision making: Review and research agenda. Journal of Management 41: 11-46.

Shier ML and Handy F (2020) Leadership in Nonprofits: Social Innovations and Blurring Boundaries. Voluntas 31: 333-344. 
Shrimali G, Slaski X, Thurber MC, et al. (2011) Improved stoves in India: A study of sustainable business models. Energy Policy 39: 7543-7556.

Siebold N, Günzel-Jensen F and Müller S (2019) Balancing dual missions for social venture growth: A comparative case study. Entrepreneurship \& Regional Development 31: 710-734.

Smith BR, Kistruck GM and Cannatelli B (2016) The impact of moral intensity and desire for control on scaling decisions in social entrepreneurship. Journal of Business Ethics 133: 677-689.

Smith BR and Stevens CE (2010) Different types of social entrepreneurship: The role of geography and embeddedness on the measurement and scaling of social value. Entrepreneurship \& Regional Development 22: 575-598.

Spieth P, Schneider S, Clauß T, et al. (2019) Value drivers of social businesses: A business model perspective. Long Range Planning 52: 427-444.

Spigel B (2017) The relational organization of entrepreneurial ecosystems. Entrepreneurship Theory and Practice 41: 49-72.

Spigel B and Harrison R (2018) Toward a process theory of entrepreneurial ecosystems. Strategic Entrepreneurship Journal 12: 151-168.

Sydow A, Cannatelli BL, Giudici A, et al. (2020) Entrepreneurial workaround practices in severe institutional voids: Evidence from Kenya. Entrepreneurship Theory and Practice in press: $1-37$.

Thompson TA, Purdy JM and Ventresca MJ (2018) How entrepreneurial ecosystems take form: Evidence from social impact initiatives in Seattle. Strategic Entrepreneurship Journal 12: $96-116$.

Tracey P and Jarvis O (2007) Toward a theory of social venture franchising. Entrepreneurship Theory and Practice 31: 667-685. 
Tracey P and Phillips N (2016) Managing the consequences of organizational stigmatization: Identity work in a social enterprise. Academy of Management Journal 59: 740-765.

Uvin P (1995) Fighting hunger at the grassroots: Paths to scaling up. World Development 23: 927-939.

Uvin P, Jain PS and Brown LD (2000) Think large and act small: Toward a new paradigm for NGO scaling up. World Development 28: 1409-1419.

VanSandt CV, Sud M and Marme C (2009) Enabling the original intent: Catalysts for social entrepreneurship. Journal of Business Ethics 90: 419-428.

Vestrum I (2014) The embedding process of community ventures: Creating a music festival in a rural community. Entrepreneurship \& Regional Development 26: 619-644.

Vickers I and Lyon F (2014) Beyond green niches? Growth strategies of environmentallymotivated social enterprises. International Small Business Journal 32: 449-470.

Vickers I, Lyon F, Sepulveda L, et al. (2017) Public service innovation and multiple institutional logics: The case of hybrid social enterprise providers of health and wellbeing. Research Policy 46: 1755-1768.

Walske JM and Tyson LD (2015) Built to scale: A comparative case analysis, assessing how social enterprises scale. International Journal of Entrepreneurship and Innovation 16: 269-281.

Wang C, Duan Z and Yu L (2016) From nonprofit organization to social enterprise: The paths and future of a Chinese social enterprise in the tourism field. International Journal of Contemporary Hospitality Management 28: 1287-1306.

Warnecke T (2018) Social entrepreneurship in China: Driving institutional change. Journal of Economic Issues 52: 368-377.

Weerawardena J, McDonald RE and Mort GS (2010) Sustainability of nonprofit organizations: An empirical investigation. Journal of World Business 45: 346-356. 
Westley F, Antadze N, Riddell DJ, et al. (2014) Five configurations for scaling up social innovation: Case examples of nonprofit organizations from Canada. Journal of Applied Behavioral Science 50: 234-260.

Wilson F and Post JE (2013) Business models for people, planet (\& profits): Exploring the phenomena of social business, a market-based approach to social value creation. Small Business Economics 40: 715-737.

Wolf M and Mair J (2019) Purpose, commitment and coordination around small wins: A proactive approach to governance in integrated hybrid organizations. Voluntas 30: 535548.

Wyper J, Whittam G and de Ruyter A (2016) Are we there yet?-Transport for Tongue Limited - A case study of a not-for-profit company in North West Sutherland. Local Economy 31: 589-601.

Yunus M (2007) Banker to the Poor: Micro-lending and the Battle Against World Poverty. New York, United States: PublicAffairs.

Zahra SA and Nambisan S (2012) Entrepreneurship and strategic thinking in business ecosystems. Business Horizons 55: 219-229.

Zhao M and Han J (2020) Tensions and risks of social enterprises' scaling strategies: The case of microfinance institutions in China. Journal of Social Entrepreneurship 11: 134-154. 


\section{Appendix: List of articles included in the review}

\begin{tabular}{|c|c|c|}
\hline \# & Authors (years) & Journals \\
\hline 1 & Albert et al. (2016) & Journal of Social Entrepreneurship \\
\hline 2 & Alshawaaf and Lee (2020) & Journal of Business Research \\
\hline 3 & Alvord et al. (2004) & The Journal of Applied Behavioral Science \\
\hline 4 & André et al. (2018) & Journal of Business Venturing \\
\hline 5 & André and Pache (2016) & Journal of Business Ethics \\
\hline 6 & Austin et al. (2006) & Entrepreneurship Theory and Practice \\
\hline 7 & Auvinet and Lloret (2015) & Canadian Journal of Administrative Sciences \\
\hline 8 & Bacq and Eddleston (2018) & Journal of Business Ethics \\
\hline 9 & Bacq et al. (2016) & Journal of Business Ethics \\
\hline 10 & Bacq et al. (2015) & $\begin{array}{l}\text { International Journal of Entrepreneurship } \\
\text { and Innovation }\end{array}$ \\
\hline 11 & Barraket (2020) & Journal of Social Entrepreneurship \\
\hline 12 & Barraket and Loosemore (2018) & Construction Management and Economics \\
\hline 13 & Battilana et al. (2015) & Academy of Management Journal \\
\hline 14 & Bauwens et al. (2020) & Organization and Environment \\
\hline 15 & Beckmann and Zeyen (2014) & Nonprofit and Voluntary Sector Quarterly \\
\hline 16 & Bhatt and Ahmad (2017) & Entrepreneurship \& Regional Development \\
\hline 17 & Bhatt et al. (2016) & Technovation \\
\hline 18 & Bhatt and Altinay (2013) & Management Decision \\
\hline 19 & Bloom and Chatterji (2009) & California Management Review \\
\hline 20 & Bloom and Dees (2008) & Stanford Social Innovation Review \\
\hline 21 & Bloom and Smith (2010) & Journal of Social Entrepreneurship \\
\hline 22 & Blundel and Lyon (2015) & Journal of Social Entrepreneurship \\
\hline 23 & Bocken et al. (2016) & Journal of Cleaner Production \\
\hline 24 & Bradach (2003) & Stanford Social Innovation Review \\
\hline 25 & Bradach $(2010)$ & Stanford Social Innovation Review \\
\hline 26 & Bruneel et al. (2016) & Journal of Social Entrepreneurship \\
\hline 27 & Cannatelli (2017) & Voluntas \\
\hline 28 & Cherrier et al. (2018) & Journal of Business Research \\
\hline 29 & Chliova and Ringov (2017) & Academy of Management Perspectives \\
\hline 30 & Corner and Ho (2010) & Entrepreneurship Theory and Practice \\
\hline 31 & Costa et al. (2011) & Voluntas \\
\hline 32 & Darby (2016) & Antipode \\
\hline 33 & Dees et al. (2004) & Stanford Social Innovation Review \\
\hline 34 & Desa and Koch (2014) & Journal of Social Entrepreneurship \\
\hline 35 & Di Domenico et al. (2010) & Entrepreneurship Theory and Practice \\
\hline 36 & Dobson et al. (2018) & Journal of Cleaner Production \\
\hline 37 & $\begin{array}{l}\text { Easter and Conway Dato-On } \\
\text { (2015) }\end{array}$ & Journal of Social Entrepreneurship \\
\hline 38 & Ebrahim and Rangan (2014) & California Management Review \\
\hline 39 & Elsayed (2018) & Voluntas \\
\hline 40 & Garrigós Simón et al. (2017) & Entrepreneurship \& Regional Development \\
\hline 41 & Giudici et al. (2020) & Entrepreneurship Theory and Practice \\
\hline 42 & Granados and Rosli (2020) & Journal of Social Entrepreneurship \\
\hline 43 & Grant and Crutchfield (2007) & Stanford Social Innovation Review \\
\hline
\end{tabular}




\begin{tabular}{|c|c|c|}
\hline$\#$ & Authors (years) & Journals \\
\hline 44 & Guha (2019) & Voluntas \\
\hline 45 & Haugh and Talwar (2016) & Journal of Business Ethics \\
\hline 46 & Henry (2015) & Journal of Social Entrepreneurship \\
\hline 47 & Hillman et al. (2018) & Energy Policy \\
\hline 48 & $\begin{array}{l}\text { Hlady-Rispal and Servantie } \\
\text { (2017) }\end{array}$ & International Small Business Journal \\
\hline 49 & Hota et al. (2019) & Management and Organization Review \\
\hline 50 & Huybrechts et al. (2017) & Entrepreneurship \& Regional Development \\
\hline 51 & Islam (2020b) & Journal of Business Venturing Insights \\
\hline 52 & Khare and Joshi (2018) & Journal of Social Entrepreneurship \\
\hline 53 & Kickul et al. (2018) & Entrepreneurship \& Regional Development \\
\hline 54 & Klein et al. (2020) & Journal of Business Research \\
\hline 55 & Kodzi Jr. (2015) & Journal of Social Entrepreneurship \\
\hline 56 & Kolk and Lenfant (2016) & Business Horizons \\
\hline 57 & Langevang and Namatovu (2019) & Entrepreneurship \& Regional Development \\
\hline 58 & Lehner and Nicholls (2014) & Venture Capital \\
\hline 59 & Leung et al. (2019) & Journal of Social Entrepreneurship \\
\hline 60 & Loosemore (2015) & Construction Management and Economics \\
\hline 61 & Lyon and Fernandez (2012) & Social Enterprise Journal \\
\hline 62 & Mair et al. (2012) & Journal of Business Ethics \\
\hline 63 & Maseno and Wanyoike (2020) & Journal of Social Entrepreneurship \\
\hline 64 & Meyskens and Bird (2015) & Entrepreneurship Research Journal \\
\hline 65 & Meyskens et al. (2010) & Entrepreneurship \& Regional Development \\
\hline 66 & Molecke and Pinkse (2017) & Journal of Business Venturing \\
\hline 67 & Mongelli et al. (2018) & Journal of Business Ethics \\
\hline 68 & Montgomery et al. (2012) & Journal of Business Ethics \\
\hline 69 & Olofsson et al. (2018) & Journal of Cleaner Production \\
\hline 70 & Ometto et al. (2019) & Business and Society \\
\hline 71 & Onyx et al. (2018) & Voluntas \\
\hline 72 & Ormiston and Seymour (2011) & Journal of Social Entrepreneurship \\
\hline 73 & Palomares-Aguirre et al. (2018) & Journal of Cleaner Production \\
\hline 74 & $\begin{array}{l}\text { Parris and McInnis-Bowers } \\
\text { (2014) }\end{array}$ & Journal of Economic Issues \\
\hline 75 & Peerally et al. (2019) & Long Range Planning \\
\hline 76 & Perrini et al. (2010) & Entrepreneurship \& Regional Development \\
\hline 77 & Phillips et al. (2019) & Journal of Business Ethics \\
\hline 78 & Pless and Appel (2012) & Journal of Business Ethics \\
\hline 79 & Powell et al. (2019) & Public Management Review \\
\hline 80 & Ramani et al. (2017) & $\begin{array}{l}\text { Technological Forecasting and Social } \\
\text { Change }\end{array}$ \\
\hline 81 & Ramus and Vaccaro (2017) & Journal of Business Ethics \\
\hline 82 & Rangan and Gregg (2019) & California Management Review \\
\hline 83 & Roy and Karna (2015) & Management Decision \\
\hline 84 & Sardana et al. (2019) & Management and Organization Review \\
\hline 85 & Saripalli et al. (2019) & Society and Business Review \\
\hline 86 & Scheuerle and Schmitz (2016) & Journal of Social Entrepreneurship \\
\hline 87 & Sengupta et al. (2020) & Journal of Cleaner Production \\
\hline
\end{tabular}




\begin{tabular}{|l|l|l|}
\hline$\#$ & Authors (years) & Journals \\
\hline 88 & Shier and Handy (2020) & Voluntas \\
\hline 89 & Shrimali et al. (2011) & Energy Policy \\
\hline 90 & Siebold et al. (2019) & Entrepreneurship \& Regional Development \\
\hline 91 & Smith et al. (2016) & Journal of Business Ethics \\
\hline 92 & Smith and Stevens (2010) & Entrepreneurship \& Regional Development \\
\hline 93 & Spieth et al. (2019) & Long Range Planning \\
\hline 94 & Sydow et al. (2020) & Entrepreneurship Theory and Practice \\
\hline 95 & Thompson et al. (2018) & Strategic Entrepreneurship Journal \\
\hline 96 & Tracey and Jarvis (2007) & Entrepreneurship Theory and Practice \\
\hline 97 & Uvin (1995) & World Development \\
\hline 98 & Uvin et al. (2000) & World Development \\
\hline 99 & VanSandt et al. (2009) & Journal of Business Ethics \\
\hline 100 & Vestrum (2014) & Entrepreneurship \& Regional Development \\
\hline 101 & Vickers and Lyon (2014) & International Small Business Journal \\
\hline 102 & Vickers et al. (2017) & Research Policy \\
\hline 103 & Walske and Tyson (2015) & $\begin{array}{l}\text { International Journal of Entrepreneurship } \\
\text { and Innovation }\end{array}$ \\
\hline 104 & Wang et al. (2016) & $\begin{array}{l}\text { International Journal of Contemporary } \\
\text { Hospitality Management }\end{array}$ \\
\hline 105 & Warnecke (2018) & Journal of Economic Issues \\
\hline 106 & Weerawardena et al. (2010) & Journal of World Business \\
\hline 107 & Westley et al. (2014) & Journal of Applied Behavioral Science \\
\hline 108 & Wilson and Post (2013) & Small Business Economics \\
\hline 109 & Wolf and Mair (2019) & Voluntas \\
\hline 110 & Wyper et al. (2016) & Local Economy \\
\hline 111 & Zhao and Han (2020) & Journal of Social Entrepreneurship \\
\hline & & \\
\hline
\end{tabular}

